\title{
The Relationship between the Internet and Foreign Direct Investments in Turkey: The Toda-Yamamoto Causality Approach
}

\author{
Dilek Tandoğan ${ }^{1, *}$, Çiğdem Karışs \\ ${ }^{1}$ Vocational School of Tourism and Hospitality, Trabzon University, Turkey \\ ${ }^{2}$ Vakfikebir Vocational School, Trabzon University, Turkey \\ Received November 24, 2019; Revised May 24, 2020; Accepted May 29, 2020
}

Copyright $\odot 2020$ by authors, all rights reserved. Authors agree that this article remains permanently open access under the terms of the Creative Commons Attribution License 4.0 International License

\begin{abstract}
This study aims to determine the relationship between foreign direct investments and the internet in Turkey. The relationship in question is researched by using annual variables for the 1993-2017 periods with the help of Toda-Yamamoto causality testing. According to the findings acquired, there is a bi-directional causal relationship between foreign direct investments and the internet. The importance of this conclusion is that it detects the increase in foreign direct investments as the number of internet users in Turkey increases. Accordingly, it can be stated that investments in the internet use can promote the inflow of foreign direct investments.
\end{abstract}

Keywords Foreign Direct Investments, Internet, Toda-Yamamoto Causality Test, Turkey

\section{Introduction}

Foreign direct investment (FDI) contributes to the economic growth processes by closing the capital account deficit needed for investments especially in developing countries. Therefore, countries that have been developing since the 1980 compete for attracting more FDI by removing restrictions on FDI inflows, by creating exclusive economic zones and providing incentives to attract foreign investments [1-3]. Thus, determining the factors that affect FDI takes place among often-researched subjects. There is an extensive literature about the determinants of FDI. However, the need for including the internet use among the factors associated with attracting FDI arises as a consequence of the developments in Information and Communication Technologies (ICT) and the world proceeds to an information-based economy rapidly [4].
The growth of ICT and the internet and internet-based technologies and services in particular have increased the efficiency in production by decreasing the cost of production, cost of inventories and cost of conveyance, and international production has been reshaped. On the other hand, this increase in question has changed the nature and competitive advantages of global relationships, and the opportunities for economic and social development radically. ICTs help countries enhance their economic potentials in terms of efficiency and competitiveness by making the exchange between all sectors possible $[2,5]$.

On the other hand, it is foreseen that the internet increases efficiency. Firstly, the internet can lower the prices by means of decreasing the costs of business to customer, business to business and business to government. The internet use lowers the cost of international communication and research, and enables entering to various markets by reducing the entry costs. Thus, both low research costs and low entry barriers create a greater market competition and productivity might increase due to the increasing competition. Along with this, the internet use reduces inventory cost by allowing large suppliers to communicate directly with customers. It is possible to say that this decrease in inventory costs contributes to the increase in productivity. Lastly, the internet use enables to do business with the country being invested in by increasing the transparency of host country.

In this context, it is possible to say that the wide use of internet decreases corruption, which increases efficiency indirectly. In conclusion, foreign investors prefer investing in countries that have a developed internet infrastructure with the effect of all these factors. In other words, it can be stated that when the internet use of a country increases, the FDI inflows of this country also increase [6]. At this point, it can be said that the development of internet infrastructure is required to attract FDI to the country and to participate in 
global markets where the competition is intense [4]. As a result, the internet takes place as an important determinant to be considered among the factors affecting FDI flows. However, the number of empirical studies in which the internet takes place among the determinants of FDI is found to be limited. In addition, there are not any studies encountered that examine this relationship for Turkey. Thus, the relationship between FDIs and the internet in Turkey is examined by the Toda-Yamamoto [15] causality approach for the 1993-2017 periods in the study to fill this gap in the literature. Accordingly, literature review related to the subject is presented in the second part of the study. Data set and econometric method and findings take place in the third and fourth parts of the study. Findings acquired from the study are evaluated in the final part.

\section{Literature Review}

In our era with rapidly improving ICT, it is seen that the number of the studies where the internet takes place among the determinants of FDI is limited. However, it is possible to say that the studies examining the internet's effect on FDI are ever-increasing along with the developments in ICT. Addison and Heshmati [4] determined that ICTs in developing countries increase FDI inflows by lowering production and transaction costs through panel data analysis. Choi [6] examined the internet's effect on FDI by using the cross-sectional regression analysis. The findings acquired revealed that the internet use increases efficiency by increasing transparency and decreasing the costs of communication, research, market entry and inventory, and the FDI inflows increase due to the impacts of all these. Similarly, Gani and Sharma [7] revealed that mobile phones and the internet increased FDI inflows for 18 developed countries in the study in which the panel regression analysis was used. Gholami et al. [2] examined the causal relationship between ICT investments and FDI in their study with the Granger causality test and panel data causality analysis for 23 countries. According to the findings acquired, there is a causal relationship from FDI to ICT investments in developing countries, while there is a uni-directional relationship determined from ICT investments to FDI in developed countries. This result reveals the importance of ICT infrastructure in attracting FDIs in developed countries. It is stated that this case is more different in developing countries and the FDI inflows increase the ICT investments. Veeramacheneni et al. [12] examined the relationship between the internet and FDI through Granger causality test and determined a bi-directional causal relationship between these two variables. On the other hand, Mottaleb [3] determined that the internet use affected FDIs positively in the study where the panel regression analysis was used for 60 developing countries. It is possible to say that such a result came up with the effect of attracting foreign investments due to the decrease in the costs of transaction, information, communication and business start-up thanks to the internet use. Similarly, Soper et al. [9], Demir et al. [14] and Ko [10] determined that the internet use affected FDI positively. Alexandar [13] concluded that there was not a relationship between the variables in question in less-developed countries although the internet affected FDI positively in developed and developing countries in a study where he used panel data analysis for 232 countries. Aytun et al. [8] revealed that the telecommunication investments affected FDI positively, however, this positive effect was stronger in the OECD countries in the study where the panel data method was used for 7 developing and 14 OECD member countries. Considering all of these conclusions, it can be stated that the internet increases FDI inflows in general, when evaluating the results of applied studies in the literature as a whole.

Summary of the studies examining the relationship between FDI and ICT is presented in Table 1.

When evaluating the results in Table 1, it is seen that the number of the studies using the cross-sectional and time series method is limited, and the applied studies examining the relationship between FDI and the internet use the panel data method for countries from different levels of income generally.

Results reveal that the internet increases FDI inflows. Along with this, there are also results revealing FDI's positive effect on the internet. Thus, the increasing internet use of the developing countries that consider FDIs as important to reach a higher level of income will cause FDI inflows to increase at the same time, and it will support the feedback process in the increase of FDIs while the growth in FDIs increases the internet use. On the other hand, it is seen that most of the studies have used the panel data method and the number of the studies using the time-series method is quite limited when the studies in the literature are examined. In this study, the relationship between FDI and the internet will be researched through the time-series method. 
Table 1. Summary of The Studies Examining The Relationship Between Foreign Direct Investments and The Internet

\begin{tabular}{|c|c|c|c|}
\hline Authors & Period/Country & Method & Findings \\
\hline Addison and Heshmati [4] & $\begin{array}{l}\text { 1970-1999/110 countries } \\
1992-1999 / 39 \text { countries }\end{array}$ & Panel Data & ICT $\rightarrow+$ FDI (Developing countries) \\
\hline Choi [6] & $\begin{array}{l}1994-1996 / 14 \text { source countries } \\
\text { and } 53 \text { host countries }\end{array}$ & Cross-sectional & $\mathrm{INT} \rightarrow+\mathrm{FDI}$ \\
\hline Gani and Sharma [7] & $\begin{array}{l}\text { 1994-1998/18 developed } \\
\text { countries }\end{array}$ & Panel Data & $\begin{array}{l}\mathrm{INT} \rightarrow+\text { FDI } \\
\mathrm{MP} \rightarrow+\text { FDI }\end{array}$ \\
\hline Gholami et al. [2] & 1976-1999/23 countries & Panel Data & $\begin{array}{l}\text { ICT } \rightarrow \text { FDI } \\
\text { (Developed countries) } \\
\text { FDI } \rightarrow \text { ICT } \\
\text { (Developing countries) } \\
\end{array}$ \\
\hline Soper et al. [9] & $1993-2003 / 29$ countries & Panel Data & ICTEXP $\rightarrow+$ FDI \\
\hline Ko [10] & $\begin{array}{l}\text { 1995-2002/106 developing and } \\
30 \text { developed countries }\end{array}$ & Panel Data & $\begin{array}{l}\text { INTEXT } \rightarrow \text {-FDI } \\
\text { countries) } \\
\text { INT EXT } \rightarrow+\text { FDI }\end{array}$ \\
\hline Mottaleb [3] & $\begin{array}{l}2003-2005 / 60 \text { developing } \\
\text { countries }\end{array}$ & Panel Data & $\mathrm{INT} \rightarrow+\mathrm{FDI}$ \\
\hline Economou [5] & $2002-2007 / 125$ countries & Table Analysis & $\begin{array}{l}\text { ICT investments are an important } \\
\text { determinant of FDIs. }\end{array}$ \\
\hline Shirazi [11] & $\begin{array}{l}1996-2005 / 7 \quad \begin{array}{r}\text { Asia-Pacific } \\
\text { countries and } 9 \text { Middle-Eastern } \\
\text { countries }\end{array} \\
\end{array}$ & Panel Data & FDI $\rightarrow+$ ICT (Asia-Pacific countries) \\
\hline Veeramacheneni et al. [12] & 1970-2005/India & Granger Causality & $\mathrm{ICT} \leftrightarrow \mathrm{FDI}$ \\
\hline Alexander [13] & $2000-2008 / 232$ countries & Panel Data & $\begin{array}{l}\text { ICTØFDI (Less-developed countries) } \\
\text { ICT } \rightarrow+\text { FDI (Developing countries) } \\
\text { ICT } \rightarrow+\text { FDI (Developed countries) }\end{array}$ \\
\hline Aytun et al. [8] & $\begin{array}{l}\text { 1975-2009/7 developing and } 14 \\
\text { OECD member countries }\end{array}$ & Panel Data & $\begin{array}{l}\text { Co-integrated } \\
\text { TELINV } \rightarrow+F D I \\
\text { TELINV↔FDI }\end{array}$ \\
\hline Demir et al. [14] & $2010-2016 / 57$ countries & $\begin{array}{l}\text { Stochastic Boundary } \\
\text { Analysis }\end{array}$ & $\mathrm{INT} \rightarrow+\mathrm{FDI}$ \\
\hline
\end{tabular}

Note: In the table above, INT, ICT, FDI, ICTEXP, INTEXT and TELINV indicate the variables of ICT, FDI, ICT expenditures, network externalities and telecommunication investments respectively; $(\rightarrow+)$ indicates positive effect; $(\rightarrow-)$ indicates negative effect; $(\varnothing)$ indicates that there is not a statistically significant relationship between the variables; $(\rightarrow)$ indicates a uni-directional causal relationship and $(\leftrightarrow)$ indicates a bi-directional causal relationship.

\section{Data Set and Econometric Method}

In this study, the relationship between the internet use and FDIs in the 1993-2017 periods is researched through the Toda-Yamamoto [15] causality test. Definitions of the variables used are presented in Table 2.

Table 2. Definitions of Variables

\begin{tabular}{|l|l|l|}
\hline Name of Variable & Definition of Variable & Source \\
\hline Ifdi & $\begin{array}{l}\text { Foreign direct investment net } \\
\text { inflows (GDP\%) }\end{array}$ & $\begin{array}{l}\text { World } \\
\text { Bank }\end{array}$ \\
\hline lint & $\begin{array}{l}\text { Number of Internet Users } \\
\text { (Population\%) }\end{array}$ & . \\
\hline
\end{tabular}

Note: ' 1 ' that takes place at the beginning of the variables states logarithmic transformation.

Toda-Yamamoto [15] causality test used in detecting the causal relationship between variables is examined through Vector Autoregressive (VAR) system that takes place in Equation (1) and Equation (2).

$$
\begin{gathered}
\text { lfdi } i_{t}=\beta_{0}+\sum_{i=1}^{k} \alpha_{1 i} \text { lfdi }_{t-i}+\sum_{i=k+1}^{k+d_{\max }} \alpha_{2 i} \text { lfdi }_{t-i}+ \\
\sum_{i=1}^{k} \emptyset_{1 i} \text { lint }_{t-i}+\sum_{i=k+1}^{k+d_{\max }} \emptyset_{2 i} \text { lint }_{t-i}+\varepsilon_{1 t} \\
\text { lint }_{t}=\delta_{0}+\sum_{i=1}^{k} \lambda_{1 i} \text { lint }_{t-i}+\sum_{i=k+1}^{k+d_{\max }} \lambda_{2 i} \text { lint }_{t-i}+
\end{gathered}
$$

$$
\sum_{i=1}^{k} \eta_{1 i} l f d i_{t-i}+\sum_{i=k+1}^{k+d_{\max }} \eta_{2 i} \text { lf } d i_{t-i}+\varepsilon_{2 t}
$$

In Toda-Yamamoto causality test, VAR system in which the level values take place is performed by estimating without looking for integration of the series at the same level. VAR system is estimated at $k+d_{\max }$ level after determining the optimal lag length $(k)$ by information criterion and determining maximum order of stationary by the unit root tests of the variables used. In the estimated $\operatorname{VAR}\left(k+d_{\max }\right)$ system, it is determined whether there is a causality relationship by equalizing the $\mathrm{k}$ lag coefficients and testing the $\mathrm{H}_{0}$ hypothesis through MWALD test. To be clearer, causality is determined by establishing the null hypotheses for equations (1) and (2) as $\quad H_{0}=\emptyset_{1 i}=0, i=1 \ldots k ; H_{0}=\eta_{1 i}=0, i=$ $1 \ldots k$ respectively and performing MWALD test for $\mathrm{k}$ lags. According to this, if the calculated MWALD test statistics is greater than $\chi^{2}$ table value with $\mathrm{k}$ degree of freedom and the null hypothesis is rejected, then a causal relationship is determined.

4. Econometric Findings

In Toda-Yamamoto (1995) [15] causality test, unit root 
tests of variables are performed at first to be able to determine $d_{\max }$. Thus, the level of stationary of lfdi and lint variables is researched through Augmented Dickey-Fuller (ADF) and Phillips-Perron (PP) unit root tests and the findings are presented in Table 3.

According to the results of ADF and PP unit root tests, lfdi variable is determined to be stationary at first level and lint variable is determined to be stationary at level as it is seen in Table 3. Thus, it is determined as $d_{\max }=1$. FPE (Final Prediction Error), AIC, SIC and HQ (Hannan-Quin Information Criterion) information criterion is used to be able to determine the optimal lag length of VAR system where the level values of lfdi and lint variables take place . The information criterion values obtained from the VAR system for 5 lags are presented in Table 4.

As it is seen in Table 4, it is determined as $k=5$. It is seen in Figure 1 that the inverse roots of the VAR (5) system take place in unit circle and the system meets the stability condition. Thus, VAR is estimated as $\left(k+d_{\max }\right)=\operatorname{VAR}(5+1=6)$ by the SUR (Seemingly Unrelated Regression) method. The SUR method estimation results of the VAR (6) system are seen in Table 5.

Table 3. Unit Root Tests Results

\begin{tabular}{|c|c|c|c|c|}
\hline \multirow{3}{*}{ Variables } & \multicolumn{4}{|c|}{$\mathrm{ADF}$} \\
\hline & \multicolumn{2}{|c|}{ Level } & \multicolumn{2}{|c|}{ At Difference } \\
\hline & Stationary & Stationary and Trend & Stationary & Stationary and Trend \\
\hline lfdi & $-1.974532(0)$ & $-2.531007(0)$ & $-5.459194^{\mathrm{a}}(0)$ & $-3.835768^{\mathrm{b}}(2)$ \\
\hline lint & $-5.209685^{\mathrm{a}}(4)$ & $-4.682597^{a}(4)$ & $-4.631869^{\mathrm{a}}(0)$ & $-7.260897^{\mathrm{a}}(0)$ \\
\hline \multirow{3}{*}{ Variables } & \multicolumn{4}{|c|}{ PP } \\
\hline & \multicolumn{2}{|c|}{ Level } & \multicolumn{2}{|c|}{ At Difference } \\
\hline & Stationary & Stationary and Trend & Stationary & Stationary and Trend \\
\hline lfdi & $-1.946941(0)$ & $-2.531007(0)$ & $-6.010754^{\mathrm{a}}(4)$ & $-5.925979^{\mathrm{a}}(4)$ \\
\hline lint & $-25.25688^{\mathrm{a}}(15)$ & $-7.155607^{\mathrm{a}}(8)$ & $-4.675330^{a}(1)$ & $-7.141767^{\mathrm{a}}(1)$ \\
\hline
\end{tabular}

Note: The optimal lag length in ADF and PP tests is chosen according to Akaike Info Criterion (AIC) and Newey-West Bandwidth respectively and shown between parantheses. $a$ and $b$ indicate $1 \%$ and $5 \%$ level of significance, respectively.

Table 4. VAR System Optimal Lag Length Estimation Results

\begin{tabular}{|c|c|c|c|c|}
\hline Lag & FPE & AIC & SC & HQ \\
\hline 0 & 0.483341 & 4.948555 & 5.048128 & 4.967992 \\
\hline 1 & 0.011017 & 1.162892 & 1.461612 & 1.221205 \\
\hline 2 & 0.013127 & 1.320998 & 1.818864 & 1.618187 \\
\hline 3 & 0.017185 & 1.550240 & 2.247253 & 1.569465 \\
\hline 4 & 0.015884 & 1.394525 & 2.290684 & $0.531139^{*}$ \\
\hline 5 & $0.006189^{*}$ & $0.317324^{*}$ & $1.412630^{*}$ & \\
\hline
\end{tabular}

Note: * indicates Optimal Lag Length. 


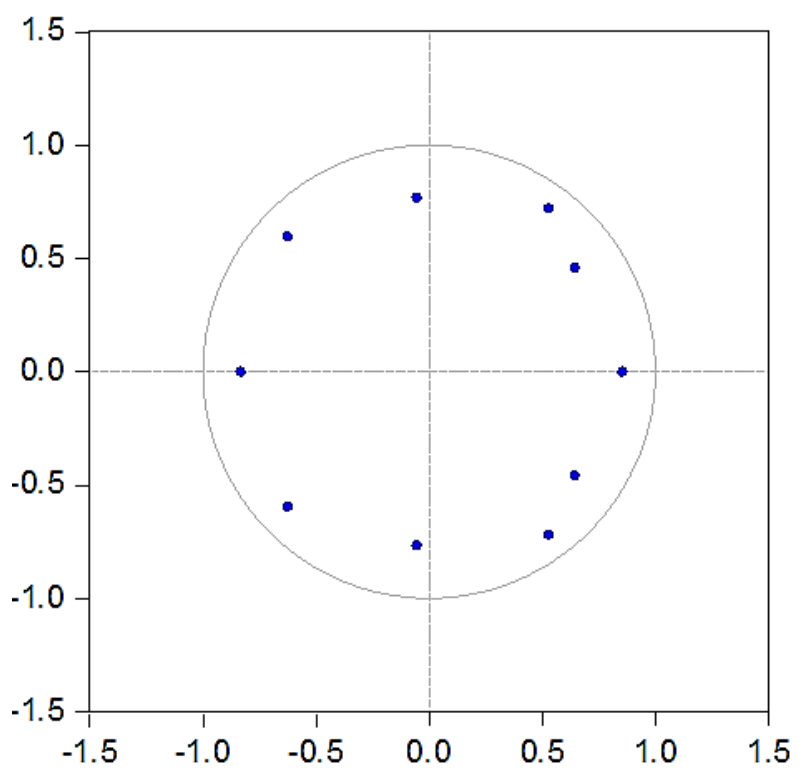

Figure 1. Inverse Roots of AR Characteric Polynomial

Table 5. Toda-Yamamoto Causality Test Results

\begin{tabular}{|c|c|c|c|c|c|}
\hline \multicolumn{7}{|c|}{ VAR $(5+1=6)$} \\
\hline Null Hypothesis & $\chi 2$ Table Value & Prob Value & Decision & Result & Evaluation \\
\hline$H_{0}=\varnothing_{11}=\varnothing_{12}=\varnothing_{13}=\varnothing_{14}=\varnothing_{15}=0$ & 67.98564 & 0.0000 & $\mathrm{H}_{0}$ is rejected & lint $\rightarrow$ lfdi & \multirow{2}{*}{ lfdi $\leftrightarrow \rightarrow$ lint } \\
\cline { 1 - 5 }$H_{0}=\eta_{11}=\eta_{12}=\eta_{13}=\eta_{14}=\eta_{15}=0$ & 26.72617 & 0.0001 & $\mathrm{H}_{0}$ is rejected & 1fdi $\rightarrow$ lint & \\
\hline
\end{tabular}

Note: $\rightarrow$ indicates the direction of causality while $\leftarrow \rightarrow$ indicate bi-directional causality.

According to the results of MWALD testing, it is determined that there is a uni-directional causal relationship from lint to lfdi by rejecting the $\mathrm{H}_{0}$ hypothesis, which determined no causality from lint to lfdi, at $1 \%$ level of significance, as it is seen in Table 5. Similarly, it is determined that there is a uni-directional causal relationship from lfdi to lint by rejecting the $\mathrm{H}_{0}$ null hypothesis, which determined no causality from lfdi to lint, at $1 \%$ level of significance. In conclusion, it is determined as there is a bi-directional causal relationship between Ifdi and lint. To sum up, it can be stated that there is a feedback process going on as the development in lint promote lfdi and the increases in lfdi also promote the development in lint.

\section{Conclusions and Evaluation}

FDIs moving between countries are considered as important for developing countries in which Turkey also takes place, since its role in financing the investments needed for the economic growth process promotes investment attraction goals. On the other hand, the internet use allows access to the information needed in today's world that is called as the era of information and communication. In this context, the subject of determining whether the internet is effective in attracting FDIs into the relevant country emerges. Moreover, not coming across to any studies about the subject in question for Turkey reveals the importance of the subject and suggests that it will fill this gap in the literature.

In the study, the relationship between FDIs and the internet in Turkey for the 1993-2017 period is researched by using annual data through Toda-Yamamoto [15] causality test. FDI is indicated by Foreign Direct Investments Net Inflows (GDP\%) and the internet is indicated by The Number of The Internet Users (Population\%). According to the findings obtained, there is a bi-directional causal relationship between FDI and the internet. > > V Veeramacheneni et al. (2008) and Aytun et al. (2015) have similar findings. The result determined for Turkey reveals that the increase in the internet use attracts FDIs to the country. In other words, it determins that the developments in the internet use affect FDIs in Turkey and support the internet use as FDI works the feedback mechanism. Thus, it reveals the internet's role in opening up to the outer world in the era of information and communication, and its effect on attracting foreign investments into the country reveals the importance of the investments in this field, accordingly. In this context, the result in question also reveals the other importance of the study as it shows policymakers that supporting the internet 
use will cause FDIs to increase.

\section{REFERENCES}

[1] A. Bende-Nabende, J. L. Ford, J. Slater, S. Sen. Foreign direct investment in East Asia: trends and determinants, The Asia Pacific Journal of Economics \& Business, Vol. 6, No. $1,4-25,2002$

[2] R. Gholami, Sang-Yong T. Lee, A. Heshmati. The casual relationship between ICT and FDI, WIDER Research Paper, No. 2005/26, 1-19, 2005.

[3] K. A. Mottaleb. Determinants of foreign direct investment and its impact on economic growth in developing countries, MPRA Paper, No: 9457, 1-15, 2007.

[4] T. Adisson, A. Heshmati. The New Global Determinants of FDI Flows to Developing Countries: The importance of ICT and democratization, WIDER Discussion Paper, No. 2003/45, 1-29, 2003.

[5] P. Economou. Harnessing ICT for FDI and development, Online available from http://www.oecd.org/investment/glo balforum/40406912.

[6] C. Choi. Does the internet inward foreign direct investment?, Journal of Policy Modeling, Vol. 25, 319-326, 2003.

[7] A. Gani, B. Sharma. The Effects of Information technology Achievement and Diffusion on Foreign direct investment, Perspective on Global Development and Technology, Vol. 2, No. 2, 161-178, 2003.

[8] C. Aytun, C.S. Akın, O. Uçan. Gelişmiş ve gelişmekte olan ülkelerde telekomünikasyon yatırımları ve doğrudan yabancı sermaye yatırımları ilişkisi, Ege Akademik Bakış, Vol. 15, No. 2, 207-216, 2015.

[9] D.S. Soper, H. Demirkan, M. Goul, R. S. Louis. The impact of ICT Eexpenditures on institutionalized democracy and foreign direct investment in developing countries, 1-10, 2006.

[10] K. W. Ko. Internet externalities and location of foreign direct investment: a comparison between developed and developing countries, Information Economics and Policy, Vol. 19, 1-23, 2007.

[11] F. Shrazi. The impact of foreign direct investment and trade openness on ICT expansion, PACIS Online available from http://aisel.aisnet.org/cgi/viewcontent.cgi?article=1209\&co ntext $=$ pacis 2008 .

[12] B. Veeramacheneni, R. Vogel, E. M. Ekanayake. Information Technology, FDI and economic growth: An India case study, Southwestern Economic Review, 95-111, 2008.

[13] D. Alexander. The relationship between information and communication technologies and foreign direct investment at the different stages of investment development path, Unpublished Doctoral Thesis, Hatfield, University of Pretoria Gordon Institute of Business Science, 2010.

[14] M. A. Demir, M. Bilik, Ü. Aydın. Siyasi ve sosyo-ekonomik göstergelerinDoğrudan yabancı yatırımlara etkisi: stokastik sınır analizi, İnsan ve Toplum Bilimleri Araștırma Dergisi, vol. 7, No. 2, 1078-1096, 2018.

[15] H.Y. Toda, T.Yamamoto. Statistical inference in vector autoregressions with possibly integrated processes, Journal of Econometrics, Vol. 66, 225-250, 1995. 